\title{
KOOS-spurningalistinn til mats á einkennum og færni í hné; réttmæti og áreiðanleiki íslenskrar pýðingar
}

Kristín Briem sjúkrapjálfari

\section{ÁGRIP}

Tilgangur: KOOS-spurningalistinn (Knee injury and Osteoarthritis Outcome Score) hefur 5 undirbætti sem meta einkenni í hné, starfræna færni við athafnir daglegs lífs, ípróttir og tómstundir, auk áhrifa skertrar færni á pátttöku einstaklingsins og lífsgæði. Hann hefur verið pýddur á mörg tungumál og gagnast bæði í klíník og fjölpjóðlegum rannsóknum. Tilgangur pessarar rannsóknar var að meta réttmæti og áreiðanleika íslenskrar pýðingar KOOS-spurningalistans og notagildi kvarðans til að mæla breytingar yfir tíma.

Efniviður og aðferðir: Alls svöruðu 145 einstaklingar listanum, og skráðu verki á VAS-kvarða (visual analog scale) og tölulegt mat á færni í hné við daglegar athafnir, auk pess sem hluti pátttakenda framkvæmdi TUG (timed up-and-go) færnipróf. Samræmi við endurteknar mælingar var metið með ICC-gildi, innra réttmæti með Cronbach's alpha, og fylgni undirbátta kvarðans við aðrar útkomumælingar var metin með Pearson‘s fylgnistuðli. Pátttakendum var skipt í hópa samkvæmt alvarleika hnékvilla og einpátta ANOVA notuð til að kanna hvort munur fyndist á meðalútkomu milli hópanna.

Niðurstöður: Marktæk breyting varð á útkomu allra undirbátta KOOS hjá peim sem fengu meðferð við hnékvilla sínum ( $p<0,001)$, en engin breyting varð milli mælinga hjá einstaklingum með óbreytt ástand í hné (ICC-gildi frá 0,825 til 0,930). Cronbach's alpha var á bilinu 0,726 til 0,966 fyrir undirpætti KOOS. Tölfræðileg fylgni fannst milli allra undirpátta KOOS og verkjamats með VAS-kvarða, tölulegs mats á eigin færni í hné og frammistöðu í TUG-prófinu ( $p<0,001)$.

Ályktun: Niðurstöður rannsóknarinnar benda til pess að íslenska KOOSspurningalistann megi nota sem klíníska mælingu og í rannsóknum til mats á einstaklingum með margvíslega hnékvilla.
Námsbraut i sjúkrapjálfun, læknadeild Háskóla íslands.

Fyrirspurnir: Kristín Briem kbriem@hi.is

Rannsóknin var unnin með aðstoð starfsfólks á Landspítala, Sjúkrahúsinu á Akureyri, endurhæfingarstofnunum á Reykjalundi og NLFÍ Hveragerði, og Sjúkrabjálfun Íslands.

Greinin barst: 22. febrúar 2012, sambykkt til birtingar: 5. júní 2012. gefin upp.

\section{Inngangur}

Mælingar á einkennum og færni einstaklinga með stoðkerfisvandamál fela gjarnan í sér einhvers konar sjálfsmat í formi spurningalista, auk færnimiðaðra prófa og sérprófa. Dæmi um einfalt sjálfsmat er svokallaður VAS-kvarði (visual analog scale) en til eru aðrir ápekkir kvarðar, par sem viðkomandi setur tölustaf sem mat á sársauka eða líkamlegri færni.1, 2 Slík mæling nær pó ekki yfir stóran hluta peirra einkenna og færniskerðinga sem fólk með stoðkerfiseinkenni upplifir, og pví hafa verið próaðir ýmsir sértækir spurningalistar til nákvæmara mats á peim páttum sem lýsa afleiðingum áverka og sjúkdóma. Mikilvægt hlýtur að teljast að pýða erlenda spurningalista á íslensku til að fjölga pekktum mælitækjum sem má nýta til að meta og endurmeta líðan, líkamsstarfsemi og lífsgæði einstaklinga með stoðkerfisvandamál hérlendis. Notkunarmöguleikar slíkra lista hafa ekki bara klínískt gildi, pví peir geta verið mikilvægt mælitæki í fjölpjóðlegum rannsóknum.

KOOS-spurningalistinn (Knee injury and Osteoarthritis Outcome Score) var próaður af Roos og félögum ${ }^{3}$ til að meta líðan og starfræna færni fólks með áverka í hné, jafnframt pví að meta áhrif skertrar færni á pátttöku og lífsgæði. Við próun listans fékkst leyfi til að taka Western Ontario and MacMaster Universities (WOMAC) slitgigtarkvarðann óbreyttan inn sem prjá af 5 undirpáttum KOOS, og er pví hægt að reikna WOMAC-skor úr KOOS-listanum. Enda pótt einstök mælitæki henti sjaldan fyrir ólíka sjúklingahópa pykir KOOS eitt af fáum sem nýtist jafnt til mats á einstaklingum eftir krossbandsslit, staðbundinn brjóskáverka eða með slitgigt í hné. ${ }^{5}$ Einnig er sýnt að listinn inniheldur spurningar sem varða mikilvæg einkenni og hreyfihömlun fólks með slitið fremra krossband, einangraða rifu í liðpófa eða slitgigt í hné. ${ }^{6}$ Pað tekur um 10 mínútur að svara listanum í heild sinni, en skor er gefið fyrir 5 undirpætti: verki (9 spurningar), önnur einkenni (7 spurningar), færni til daglegra athafna (17 spurningar), færni til að sinna ípróttum og tómstundum (5 spurningar) og lífsgæði (4 spurningar). Svörin gefa hvert um sig 0-4 stig, en stigafjöldi hvers undirpáttar er umreiknaður í skor frá 0-100, par sem 100 bendir til engra einkenna eða færniskerðingar. Listinn hefur verið pýddur á fjölmörg tungumál og réttmæti og áreiðanleiki pýddra spurningalista verið staðfestur. ${ }^{7-12}$ Íslensk pýðing á listanum hefur ekki verið prófuð og pví var tilgangur pessarar rannsóknar að meta réttmæti og áreiðanleika íslenskrar pýðingar KOOS-spurningalistans og notagildi kvarðans til að mæla breytingar yfir tíma með pví að prófa hvort: 1) Marktæk breyting yrði á skori eftir meðferð (responsiveness), á meðan engin breyting yrði hjá einstaklingum sem fengu ekki meðferð; 2) sýnt yrði fram á innri áreiðanleika (internal consistency) allra pátta 


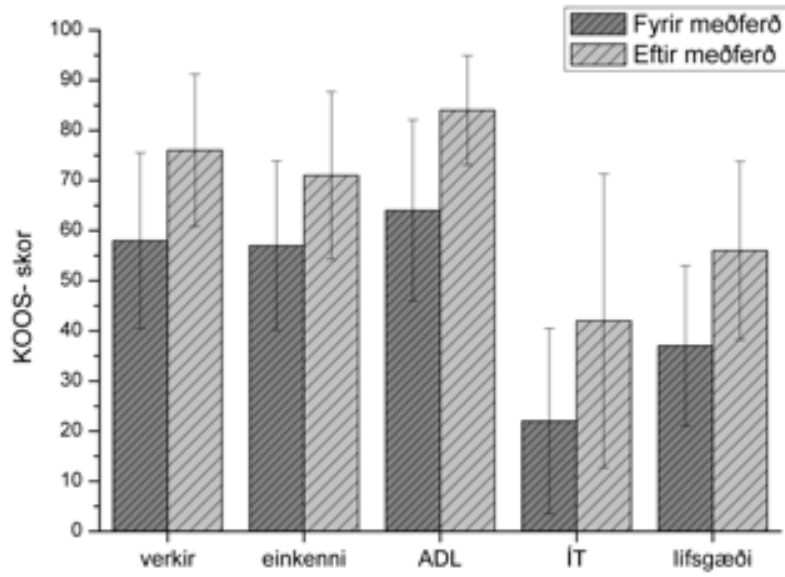

Mynd 1. Meðalskor (staðalfrávik) hvers undirpáttar KOOS fyrir og eftir meðferð við hnékvilla. $A D L=$ athafnir daglegs lífs. ÍT=ípróttir og tómstundir. Marktækur munur fannst milli fyrri og seinni mælingar allra pátta listans $(p<0,001)$.

listans; 3) tölfræðileg fylgni væri milli mælinga KOOS-listans og annarra tengdra útkomumælinga; 4) greina mætti milli priggja hópa með misalvarlega hnékvilla með skorum KOOS-listans, en alvarleiki var skilgreindur út frá peim úrræðum sem sóst var eftir. Vinnutilgáturnar voru pær að skor allra undirpátta KOOS myndi hækka marktækt hjá fólki sem sótti meðferð, á meðan samræmi milli endurtekinna mælinga yrði hjá peim sem ekki hlutu meðferð; að fylgnistuðull yrði hæstur milli pess undirpáttar KOOS sem best tengdist samanburðarmælingunni; að meðalútkoma undirpátta KOOS yrði ólík milli priggja hópa fólks með misalvarlega hnékvilla (hópur með alvarlegri hnékvilla fengi peim mun lægra skor).

\section{Efniviður og aðferðir}

Stöðluð aðferð var notuð við pýðingu, bakpýðingu og forprófun listans ${ }^{13,14}$ og leyfi fyrir rannsókninni fengið hjá vísindasiðanefnd, auk pess sem hún var tilkynnt til Persónuverndar. Alls fengust 145 manns til pátttöku og komu úr samfélagi Háskóla Íslands (auglýst var eftir einstaklingum sem fundu fyrir einkennum í hné en leituðu ekki eftir meðferð á peim tíma; n=28), af tveimur endurhæfingarstofnunum par sem fólk dvelur í lengri eða skemmri tíma og af sjúkrapjálfunarstofu í Reykjavík (sjúkrapjálfarar kynntu rannsóknina fyrir einstaklingum sem voru í virkri meðferð við hnékvilla; n=55), og af tveimur spítölum (sjúkrapjálfarar eða hjúkrunarfræðingar kynntu rannsóknina fyrir einstaklingum sem voru á leið í liðskipti; $n=62$ ). Skipun í hópa valt á alvarleika hnékvillans, byggt á pví hvort einstaklingur sóttist eftir virkri meðferð (M) eða ekki (E), eða liðskiptum (L). Algengustu sjúkdómsgreiningarnar voru slitgigt í hné, áverki á hnéskel, liðpófa eða -bönd, festumein eða óskilgreind ópægindi frá hné. Meðalaldur (staðalfrávik) pátttakenda var 55,6 (18,5) og líkamspyngdarstuðull 24,8 (4,5) (tafla I). Útilokaðir frá pátttöku voru peir sem fundu fyrir einkennum frá öðrum liðamótum ganglima en hné. Ef einkenni voru frá báðum hnjám var viðkomandi beðinn að svara með tilliti til pess sem olli meiri einkennum og/eða færniskerðingu.

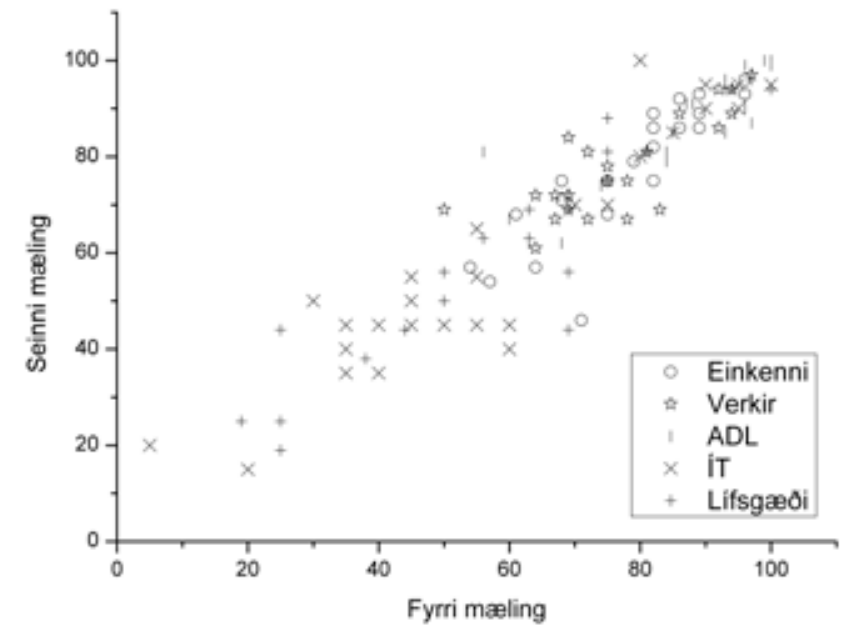

Mynd 2. Skor undirpátta KOOS við endurteknar mælingar á óbreyttu ástandi. $A D L=$ athafnir daglegs lífs. ÍT = ípróttir og tómstundir.

Auk pess að svara KOOS-listanum, skráðu pátttakendur hnéverk á 100 millimetra (mm) VAS-kvarða ${ }^{15}$ og skráðu eigið mat á starfrænni færni í hné við athafnir daglegs lífs með pví að velja tölustaf frá 0 til 100, par sem 100 gaf til kynna færni fyrir hnéáverka. ${ }^{2}$ Að auki var hluti pátttakanda $(n=67)$ prófaður með ,timed up-and-go' (TUG)-prófinu ${ }^{16}$ sem er tímataka við pað að standa upp úr stól, ganga 3 metra, snúa við, ganga til baka og setjast. Prófið var notað fyrir aldraða og aðra pátttakendur sem áttu í erfiðleikum með pá pætti sem prófið metur; almenna göngufærni og jafnvægi. Hópur pátttakenda $(n=28)$, sem ekki voru í meðferð vegna hnékvillans og lýst höfðu einkennum sínum sem nokkuð stöðugum, fyllti listann út í tvígang með að jafnaði 6,4 (5,8) daga millibili til að prófa áreiðanleika hans. Annar hópur fólks $(n=28)$ svaraði KOOS með að meðaltali 27 (15) daga millibili ásamt pví að skrá verki og mat á færni, fyrir og eftir að hafa fengið meðferð vegna hnékvillans, til að kanna breytingu á pessum mælingum. Færni 13 peirra var einnig prófuð með TUG.

Við tölfræðiúrvinnslu var notaður ICC $_{2,1}$ áreiðanleikastuðull með 95\% öryggismörkum ${ }^{17}$ til að meta áreiðanleika endurtekinna mælinga (test-retest). Fyrirfram var ákveðið að ICC yfir 0,70 og neðri öryggismörk yfir 0,60 yrði ásættanleg niðurstaða. ${ }^{18}$ Staðalvilla mælingarinnar (standard error of the measurement, SEM), sem gefur til kynna skekkju milli endurtekinna mælinga, var reiknuð, og notuð til að reikna pá stærð sem gefur til kynna mælanlega breytingu yfir tíma (minimal detectable difference, $M D D$ ). Pöruð tpróf voru notuð til að meta pá breytingu á KOOS-skori sem varð hjá peim sem hlutu meðferð við hnékvilla sínum. Innri áreiðanleiki undirpátta listans var metinn með Cronbrach's alpha og var ákveðið að sá stuðull yrði að ná í pað minnsta 0,70 til að pykja ásættanlegt. ${ }^{18}$ Réttmæti var metið með Pearsons-fylgnistuðli vegna tengsla milli KOOS og annarra mælinga (VAS, tölulegt mat á starfrænni færni í hné, TUG). Mismunur á útkomum hjá hópunum premur (M, E, og L) var metinn með einhliða greiningu á breytileika (ANOVA). Miðað var við marktektarmörk $\mathrm{p}<0,05$. Við tölfræðiúrvinnslu var notaður SPSS®-hugbúnaður (PASW Statistics 18, SPSS Inc, Chicago, IL). 
Tafla I. Meðaltal (staðalfrávik) grunnupplýsinga pátttekanda samkvæmt hópaskiptingu.

\begin{tabular}{|c|c|c|c|c|}
\hline & Engin meðferð $(E)$ & Virk meðferð (M) & Liðskipti (L) & Allir \\
\hline Aldur * & $38,6(20,1)$ & $51,3(16,6)$ & $67,0(10,1)$ & $55,6(18,5)$ \\
\hline Líkamspyngdarstuðull † & $21,5(3,1)$ & $25,8(4,9)$ & $25,3(4,0)$ & $24,8(4,5)$ \\
\hline VAS * & $2,2(1,7)$ & $4,6(2,3)$ & $6,0(2,5)$ & $4,6(2,7)$ \\
\hline Almenn færni * & $89,8(12,0)$ & $61,9(23,1)$ & $46,6(23,0)$ & $64,2(26,2)$ \\
\hline KOOS-verkir $\dagger$ & $82,3(9,7)$ & $58,8(17,9)$ & $48,6(15,8)$ & $58,9(19,9)$ \\
\hline KOOS-einkenni $\ddagger$ & $79,8(10,7)$ & $54,0(18,6)$ & $50,7(17,4)$ & $57,5(20,0)$ \\
\hline KOOS-ADL $†$ & $92,5(8,2)$ & $67,0(18,4)$ & $55,5(16,7)$ & $67,3(21,0)$ \\
\hline KOOS-ÍT ¥ & $65,4(20,2)$ & $24,7(21,4)$ & $18,3(15,8)$ & $30,6(26,2)$ \\
\hline KOOS-lífsgæði † & $65,1(15,5)$ & $41,6(18,5)$ & $25,6(13,4)$ & $39,6(21,6)$ \\
\hline
\end{tabular}

*tölfræðilega marktækur munur á meðaltali allra hópa ( $\leq \leq 0,001)$, †tölfræðilega marktækur munur á meðaltali allra hópa ( $p<0,01)$, łtölfræðilega marktækur munur á meðaltali $E$ og M hópa og međaltali $\mathrm{E}$ og $\mathrm{L}$ hópa $(\mathrm{p}<0,001)$. $\mathrm{ADL}=$ athafnir daglegs lífs, i $\mathrm{I}=$ ípróttir og tómstundir.

\section{Niðurstöður}

Marktæk breyting varð á skorum allra undirpátta KOOS hjá peim sem fengu meðferð við hnékvilla sínum ( $<<0,001$; mynd 1). Á sama tíma minnkuðu verkir samkvæmt VAS-kvarðanum ( $\mathrm{p}<0,001)$, mat á eigin færni batnaði $(\mathrm{p}=0,001)$ og bæting varð hjá peim 13 einstaklingum sem metnir voru með TUG-prófinu $(p=0,002)$. Hins vegar breyttist skor ekki milli mælinga hjá einstaklingum með óbreytt ástand í hné (mynd 2) og lágu ICC-gildi á bilinu 0,825 til 0,930 (tafla II) og neðri öryggismörk voru lægst við 0,657.

Innra réttmæti var metið með Cronbach's alpha, sem var á bilinu 0,726 til 0,966 fyrir hvern undirpátt KOOS-listans, en SEM var frá 2,5 til 3,8 og MDD frá 7,0 til 10,4 (tafla II).

Tölfræðileg neikvæð fylgni fannst milli allra undirpátta KOOS og verkjamats með VAS-kvarða, par sem minni verkir gáfu lægra VAS-skor en hærra (betra) KOOS-skor. Sterkustu tengslin voru milli verkjapáttar KOOS og VAS, ( $\mathrm{r}=-0,772 ; \mathrm{p}<0,001$, mynd 3). Marktæk jákvæð fylgni var á milli tölulegs mats á eigin færni í hné við daglegar athafnir og allra undirpátta KOOS, en sterkust voru tengslin við undirpátt athafna daglegs lífs $(r=0,781 ; p<0,001)$. Pá var marktæk neikvæð fylgni milli frammistöðu í TUG-prófinu og útkomu allra undirpátta KOOS, en sterkust voru tengsl við ípróttaog tómstundapátt KOOS ( $\mathrm{r}=-0,495 ; \mathrm{p}<0,001)$.

Samantekt á meðaltali mælinga samkvæmt hópaskiptingu pátttakenda má finna í töflu I. Munur var á meðalaldri allra hópa $(\mathrm{p} \leq 0,001)$ og pátttakendur í E-hóp voru almennt léttari en peir sem voru í M- og L-hópunum ( $\mathrm{p}<0,001)$. Marktækur munur var á meðaltali undirpátta fyrir verki, færni til athafna daglegs lífs og lífsgæði $(p<0,01)$ milli allra hópa. Ekki var tölfræðilega marktækur munur milli M- og L-hópa á meðaltali undirpátta einkenna annars vegar og íprótta og tómstunda hins vegar, en báðir fengu marktækt lægri útkomu en pátttakendur í E-hóp $(\mathrm{p}<0,001)$.

Tafla II. Gildi tengd mati á áreiðanleika og innra réttmætis undirpátta KOOS.

\begin{tabular}{lccccc}
\hline & Verkir & Einkenni & ADL & ÍT & Lífsgæði \\
\hline ICC-gildi & 0,825 & 0,863 & 0,884 & 0,930 & 0,926 \\
\hline SEM & 2,8 & 2,6 & 2,5 & 3,8 & 3,2 \\
\hline MDD & 7,7 & 7,3 & 7,0 & 10,4 & 8,9 \\
\hline Cronbach's alpha & 0,920 & 0,726 & 0,966 & 0,925 & 0,830 \\
\hline
\end{tabular}

$\mathrm{ADL}=$ athafnir daglegs lífs. I $\mathrm{T}=$ ipróttir og tómstundir. $\mathrm{ICC}=$ intra-class correlation coefficient. SEM = staðalvilla mælingar (standard error of the measurement). MDD = minnsti mælanlegi munur (minimal detectable difference).

\section{Umræða}

Markmið rannsóknarinnar var að kanna próffræðilega eiginleika íslensku útgáfu KOOS-spurningalistans. Niðurstöður benda til pess að íslenska útgáfan sé réttmæt og áreiðanleg og næm á breytingar yfir tíma. Petta er í samræmi við birtar niðurstöður vegna prófana á fyrri pýðingum..$^{7-12}$

Áreiðanleg mælitæki gefa sömu útkomu við endurteknar mælingar og var samkvæmni milli endurtekinna mælinga KOOSlistans metin. ICC-áreiðanleikastuðull undirpátta KOOS, sem og neðri öryggismörkin, voru ofan peirra marka sem sett voru til viðmiðunar um ásættanleg gildi og í samræmi við pað sem áður hefur komið fram við prófanir pessa mælitækis. ${ }^{8-11}$ Enda pótt gert sé ráð fyrir óbreyttu ástandi og óbreyttum aðstæðum við mælingar er pað sjaldan raunin. Með pví að velja fólk sem lýsti ástandinu sem stöðugu var hægt að hafa góðan tíma milli mælinga og draga pannig verulega úr minnisbjögun. Peir sem tóku pátt í pessum hluta rannsóknarinnar voru hins vegar fæstir með svæsin einkenni eða mikla færniskerðingu, sem gæti haft áhrif á ytra réttmæti niðurstaðna. Staðalvilla var almennt nokkuð lág miðað við pað sem aðrar prófanir á pýddum listum hafa sýnt ${ }^{8,10}$

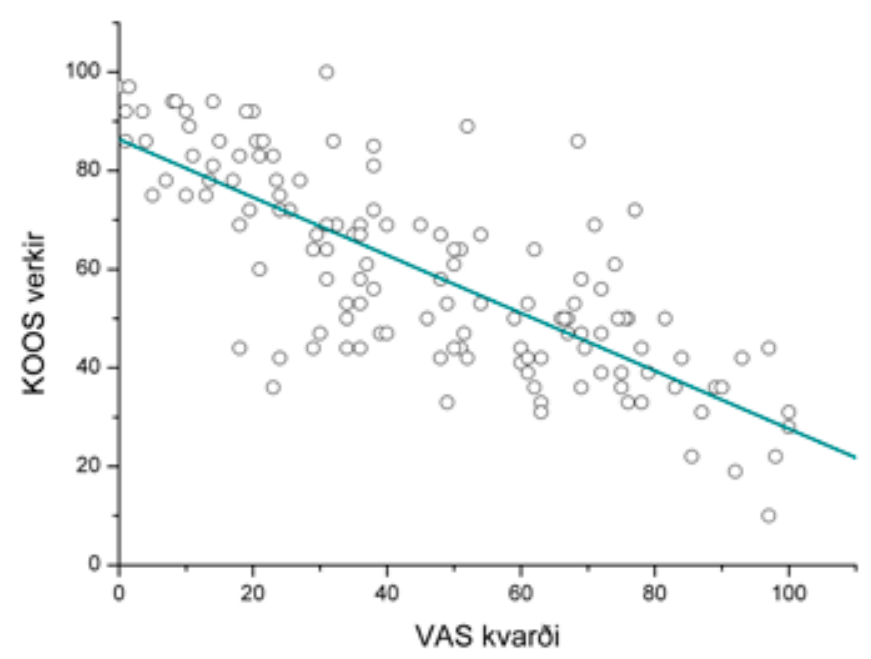

Mynd 3. Tengsl milli verkja á VAS-kvarða (hærra skor gefur til kynna meiri verki) og KOOS-verkjapáttar (hærra skor gefur til kynna minni verki). 
og styður sú niðurstaða mat á áreiðanleika mælitækisins. Reiknað MDD-gildi var á bilinu 7 til 10,5 sem er í samræmi við lága staðalvillu og heldur lægra en áður hefur verið nefnt fyrir pennan lista. ${ }^{19}$ Breyting varð hjá peim einstaklingum yfir pann tíma sem peir hlutu meðferð við hnékvilla sínum, eins og búist hafði verið við, og mæld breyting mun meiri en reiknað MDD-gildi, sem gefur til kynna að breytingin hafi verið klínískt mikilvæg.

Gildin fyrir Cronbach's alpha voru ofan pess viðmiðs sem notað var sem ásættanlegt fyrir alla undirpætti KOOS. Gildið fyrir ADLundirpáttinn er mjög hátt og hefur sú verið raunin í öðrum rannsóknum $^{8,9,11}$ og vakið spurningar um hvort einhverjum af peim 17 spurningum pess undirpáttar sé ofaukið. Hins vegar er á pað að líta að pessi páttur listans inniheldur langflestar spurningar, sem getur líka að einhverju leyti skýrt hærra Cronbach's alpha gildi. ${ }^{20}$ Lægsta gildið var fyrir pann undirpátt sem snýr að hnéeinkennum, enda er par helst að finna spurningar sem vísa til ólíkra og oft ótengdra einkenna hnéliðar, og pví við pessu að búast. Sýnt hefur verið fram á sterk tengsl milli innra réttmætis mælitækis og getu pess til að sýna mælanlega breytingu. ${ }^{21}$ Höfundarnir ályktuðu að innra réttmæti endurspegli möguleika mælitækisins til að meta breytingar yfir tíma og eru niðurstöður pessarar rannsóknar í samræmi við pað.

Tölfræðileg fylgni fannst milli allra undirpátta KOOS-listans og peirra mælinga sem notaðar voru til samanburðar og studdu niðurstöður varðandi réttmæti mælitækisins. Eins og búist hafði verið við og í samræmi við pað sem aðrir hafa sýnt ${ }^{9}$ voru sterkust tengslin milli VAS og verkjapáttar KOOS, og í samræmi við vinnutilgátur voru tengslin milli tölulegs mats pátttakenda á færni í hné við daglegar athafnir sterkust við ADL-undirpátt listans. Mat á færni með TUG-prófinu var notað fyrir eldri einstaklinga og pá sem áttu í erfiðleikum með pá pætti sem reynir á í prófinu, pví pakáhrif hafa áhrif á mælingar ef fólk er líkamlega vel á sig komið. Prófið krefst pess að fólk reyni að framkvæma prautina hratt, enda pótt um stuttan veg sé farið. Pví kemur ekki á óvart að hjá peim hópi fólks sem voru prófaðir með TUG, kom fram sterkust tölfræðileg fylgni við íprótta- og tómstundapátt KOOS. Aðrar birtar rannsóknir virðast ekki hafa notað færnipróf sem petta til mats á réttmæti, heldur notað annars konar spurningalista til að meta líkamlegt ástand. ${ }^{7-11}$ Almennt er talið að fólk hafi tilhneigingu til að meta færni sína betri en hún mælist við færnimiðaðar prófanir ${ }^{22-24}$ og í ljósi pess má segja að pessi niðurstaða sé mikilvæg hvað varðar réttmæti kvarðans, en hafa ber í huga að aðeins hluti pátttakenda var prófaður með TUG, sem rýrir ytra réttmæti pessa páttar.

Enda pótt allir pátttakendur hafi fundið fyrir einkennum frá hné sem höfðu áhrif á daglegar athafnir er við pví að búast að peir sem eru á leið í liðskiptaaðgerð séu verr staddir en peir sem ekki leita sérstakrar meðferðar við sínum hnékvilla. Mælingar sýndu pennan mun milli okkar hópa með óyggjandi hætti, sem og milli peirra sem hlutu virka meðferð við hnékvilla og hinna sem ekki sóttu meðferð. Hins vegar var ekki tölfræðilega marktækur munur milli peirra tveggja hópa með alvarlegri einkenni hvað varðar tvo af undirpáttum KOOS (einkenni, og ípróttir og tómstundir). Í rannsókn Ornetti ${ }^{11}$ voru bornir saman prír hópar með mismikið slit í hné og fannst tölfræðilegur munur milli hópar við alla undirpætti. Meðalútkoma allra undirpátta í peirri rannsókn hjá besta og versta hópnum var sambærileg pví sem kom fram hjá besta og versta hóp pessarar rannsóknar, en útkomumælingar meðferðarhóps pessarar rannsóknar voru hins vegar lakari en miðjuhóps Ornetti. Sá hópur sem sótti virka meðferð í pessari rannsókn hafði að jafnaði töluverð einkenni frá hné sem skerti verulega getu peirra til athafna tengdum ípróttum og tómstundum, líkt og hjá peim sem voru á leið í aðgerð. Рað sem skildi hins vegar á milli pessara hópa með tölfræðilega marktækum hætti voru prír pættir: verkir, færni við athafnir daglegs lífs, og lífsgæði, sem eru einmitt mikilvægustu atriðin pegar kemur að ákvörðun um liðskiptaaðgerð. ${ }^{25}$

Niðurstöður rannsóknarinnar benda til pess að íslenski KOOSspurningalistinn sé réttmætt og áreiðanlegt mælitæki. Listinn kemur að góðum notum við klínískt mat á einstaklingum með margvíslega hnékvilla og endurteknar mælingar geta gefið til kynna hvort einstaklingum versni yfir tímabilið eða breyting verði til batnaðar, til dæmis eftir endurhæfingu eða læknisfræðilegt inngrip. Mælitæki sem byggja á sjálfsmati hafa sínar takmarkanir prátt fyrir augljóst notagildi, og færnimiðað mat með viðeigandi prófunum ætti einnig að framkvæma til að fá heildrænt mat á starfrænni færni einstaklingsins.

\section{Pakkir}

Pakkir fá pátttakendur, sem og sjúkrapjálfarar og annað starfsfólk á Reykjalundi, Sjúkrapjálfun Íslands, í Hveragerði, á Landspítala og Sjúkrahúsinu á Akureyri. Án peirra hefði pessi rannsókn ekki verið möguleg. Styrkir til verkefnisins voru veittir úr pýðingasjóði og vísindasjóði Félags íslenskra sjúkrapjálfara. 


\section{Heimildir}

1. Carlsson AM. Assessment of chronic pain. I. Aspects of the reliability and validity of the visual analogue scale. Pain 1983; 16: 87-101

2. Ornetti P, Dougados M, Paternotte S, Logeart I, Gossec L Validation of a numerical rating scale to assess functional impairment in hip and knee osteoarthritis: comparison with the WOMAC function scale. Ann Rheum Dis 2011; 70: 740-6.

3. Roos EM, Roos HP, Lohmander LS, Ekdahl C, Beynnon $\mathrm{BD}$. Knee Injury and Osteoarthritis Outcome Score (KOOS)--development of a self-administered outcome measure. J Orthop Sports Phys Ther 1998; 28: 88-96.

4. Bellamy N, Buchanan WW, Goldsmith CH, Campbell J, Stitt LW. Validation study of WOMAC: a health status instrument for measuring clinically important patient relevant outcomes to antirheumatic drug therapy in patients with osteoarthritis of the hip or knee. J Rheumatol 1988; 15: 1833-40.

5. Wang D, Jones MH, Khair MM, Miniaci A. Patientreported outcome measures for the knee. J Knee Surg 2010; 23: 137-51.

6. Tanner SM, Dainty KN, Marx RG, Kirkley A. Kneespecific quality-of-life instruments: which ones measure symptoms and disabilities most important to patients? Am J Sports Med 2007; 35: 1450-8.

7. Salavati M, Mazaheri M, Negahban H, Sohani SM, Ebrahimian MR, Ebrahimi I, et al. Validation of a Persianversion of Knee injury and Osteoarthritis Outcome Score (KOOS) in Iranians with knee injuries. Osteoarthritis Cartilage 2008; 16: 1178-82.

8. Goncalves RS, Cabri J, Pinheiro JP, Ferreira PL. Crosscultural adaptation and validation of the Portuguese version of the Knee injury and Osteoarthritis Outcome Score (KOOS). Osteoarthritis Cartilage 2009; 17: 1156-62.
9. de Groot IB, Favejee MM, Reijman M, Verhaar JA, Terwee CB. The Dutch version of the Knee Injury and Osteoarthritis Outcome Score: a validation study. Health Qual Life Outcomes 2008; 6: 16.

10. Nakamura N, Takeuchi R, Sawaguchi T, Ishikawa H, Saito T, Goldhahn S. Cross-cultural adaptation and validation of the Japanese Knee Injury and Osteoarthritis Outcome Score (KOOS). J Orthop Sci 2011; 16: 516-23.

11. Ornetti P, Parratte S, Gossec L, Tavernier C, Argenson JN, Roos EM, et al. Cross-cultural adaptation and validation of the French version of the Knee injury and Osteoarthritis Outcome Score (KOOS) in knee osteoarthritis patients. Osteoarthritis Cartilage 2008; 16: 423-8.

12. Roos EM, Roos HP, Ekdahl C, Lohmander LS. Knee injury and Osteoarthritis Outcome Score (KOOS)--validation of a Swedish version. Scand J Med Sci Sports 1998; 8: 439-48.

13. Assessing health status and quality-of-life instruments: attributes and review criteria. Qual Life Res 2002; 11: 193205.

14. Beaton DE, Bombardier C, Guillemin F, Ferraz MB Guidelines for the process of cross-cultural adaptation of self-report measures. Spine (Phila Pa 1976. 2000; 25: 318691.

15. Crossley KM, Bennell KL, Cowan SM, Green S. Analysis of outcome measures for persons with patellofemoral pain: which are reliable and valid? Arch Phys Med Rehabil 2004; 85: 815-22.

16. Podsiadlo D, Richardson S. The timed „Up \& Go“: a test of basic functional mobility for frail elderly persons. J Am Geriatr Soc 1991; 39: 142-8.

17. Shrout PE, Fleiss JL. Intraclass correlations: uses in assessing rater reliability. Psychol Bull 1979; 86: 420-8.
18. Terwee CB, Mokkink LB, Steultjens MP, Dekker J. Performance-based methods for measuring the physical function of patients with osteoarthritis of the hip or knee: a systematic review of measurement properties. Rheumatology (Oxford) 2006; 45: 890-902.

19. Logerstedt DS, Snyder-Mackler L, Ritter RC, Axe MJ. Knee pain and mobility impairments: meniscal and articular cartilage lesions. J Orthop Sports Phys Ther 2010; 40: A1-A35.

20. Portney LG, Watkins MP. Foundations of Clinical Research Applications to Practice. In: Cohen M, ed. 3 ed. Pearson Education Ltd, New Jersey 2009.

21. Lindeboom $\mathrm{R}$, Sprangers MA, Zwinderman $\mathrm{AH}$. Responsiveness: a reinvention of the wheel? Health Qual Life Outcomes 2005; 3: 8 .

22. Briem K, Axe MJ, Snyder-Mackler L. Functional and perceived response to intra-articular hyaluronan injection in patients with knee osteoarthritis: persistence of treatment effects over 5 months. Knee Surg Sports Traumatol Arthrosc 2009; 17: 763-9.

23. Eitzen I, Moksnes H, Snyder-Mackler L, Engebretsen L, Risberg MA. Functional tests should be accentuated more in the decision for ACL reconstruction. Knee Surg Sports Traumatol Arthrosc 2010; 18: 1517-25.

24. Mizner RL, Petterson SC, Clements KE, Zeni JA Jr, Irrgang JJ, Snyder-Mackler L. Measuring functional improvement after total knee arthroplasty requires both performancebased and patient-report assessments: a longitudinal analysis of outcomes. J Arthroplasty 2011; 26: 728-37.

25. NIH Consensus Statement on total knee replacement. NIH Consens State Sci Statements 2003; 20: 1-34.

\section{ENGLISH SUMMARY}

\section{Reliability, validity and responsiveness of the Icelandic version of the knee injury and osteoarthritis outcome score (KOOS)}

\section{Briem K}

Purpose: The KOOS self-report questionnaire (Knee injury and Osteoarthritis Outcome Score) has 5 sub-scales, assessing knee symptoms and function, and quality of life. It is widely used as it has been found to be a valid and reliable measure. The purpose of this study was to investigate the validity, reliability and responsiveness of the Icelandic translation of KOOS.

Methods: A total of 145 were recruited for the study and in addition to answering KOOS, knee pain was rated on a visual analog scale (VAS), perception of knee function during activities of daily living on a numerical rating scale, and some were tested with the timed up-and-go test (TUG). Reliability was assessed by observing ICC-values, internal consistency with Cronbach's alpha, and associations between KOOS subscales and other outcome measures with Pearson's correlation coefficient. A one-way ANOVA was used to assess differences between groups of participants with different levels of knee dysfunction. Results: A significant change in all KOOS subscales was found in a group of individuals seeking treatment for their knee dysfunction $(p<0.001)$, while no change was seen in a group reporting stable knee status (ICC-values ranging from 0.825 to 0.930 ). Cronbach's alpha ranged from 0.726 to 0.966 and significant correlations were found between all KOOS sub-scales and other outcome measures $(p<0.001)$.

Conclusion: The results indicate that the Icelandic version of KOOS is a valid and reliable measure that may be used as an outcome measure assessing knee symptoms and function of individuals with knee symptoms and impaired knee function.

Key words: Knee, Questionnaire, Function, Symptoms, Self-report, KOOS.

Correspondence: Kristín Briem, kbriem@hi.is

Department of Physical Therapy, Faculty of Medicine, School of Health Sciences, University of Iceland, Reykjavík, Iceland. 